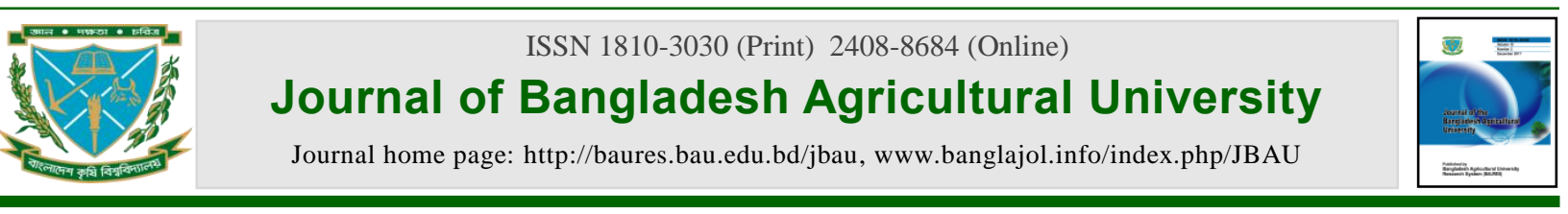

\title{
Grain filling patterns of barley as affected by high temperature stress
}

\author{
Md Rasel Rana ${ }^{1}$, Md Masudul Karim ${ }^{2}$, Md Juiceball Hassan ${ }^{2}$, Md Alamgir Hossain ${ }^{2}$ and Md Ashraful Haque ${ }^{3}$ \\ ${ }^{1}$ Department of Seed Science and Technology, Bangladesh Agricultural University, Mymensingh-2202, Bangladesh \\ ${ }^{2}$ Department of Crop Botany, Bangladesh Agricultural University, Mymensingh-2202, Bangladesh \\ ${ }^{3}$ Department of Genetics and Plant Breeding, Bangladesh Agricultural University, Mymensingh-2202, Bangladesh
}

\section{ARTICLE INFO}

Article history:

Received: 19 October 2017

Accepted: 25 November 2017

Keywords:

Grain filling, water soluble carbohydrates, culm reserves, heat stress, barley

\section{Correspondence:}

Md Alamgir Hossain

(alamgircbot@bau.edu.bd)

\begin{abstract}
Grain filling determines the grain weight, a major component of grain yield in cereals. Grain filling in barley depends on current assimilation and culm reserves (mainly water soluble carbohydrates). Nowadays barley is facing heat stress problem which is mostly responsible to reduce the yield of barley. A field experiment was conducted at the Field Lab, Department of Crop Botany, Bangladesh Agricultural University, Mymensingh during November 2015 to March 2016 to study the grain filling patterns and the contributions of culm reserves to grain yield under heat stress. The experiment consisted of two factorsbarley cultivars and heat stress. The heat stress was imposed by late sowing. The tillers were sampled once a week during grain filling period to determine the changes in dry weights of different parts, viz., leaves, culm with sheath, spikes, and grains; and to examine the contribution of culm reserves to grain yield. The results in the experiment revealed that the grain yield was reduced by $22-28 \%$ due to the stress. The grain yield varied from 52 to $150 \mathrm{~g} \mathrm{~m}^{-2}$ with the mean of $102 \mathrm{~g} \mathrm{~m}^{-2}$ under control while it varied from 37 to 116 $\mathrm{g} \mathrm{m}^{-2}$ with the mean of $75 \mathrm{~g} \mathrm{~m}^{-2}$ under heat stress. Among the cultivars studied BARI Barley5, BARI Barley2 and BARI Barley1, seemed as high yielders while BARI Barley3, BARI Barley4, BARI Barley6 as the low yielders under heat stress treatment. The reduction in grain yield was attributable mainly to lighter grain weight due to the stress. Heat stress drastically reduced the grain filling duration by $45-50 \%$. However, the stress increased the grain filling rate by $6-53 \%$. The amount of reserves remobilized to grain varied among the cultivars ranging from 4.8 to $12.77 \mathrm{mg} \mathrm{spike}^{-1}$ in control and from 1.73 to $6.25 \mathrm{mg}$ spike $^{-1}$ in stressed plants. The stressed barley plants exhibited lower accumulation of reserves in culm but they showed almost its complete remobilization to the grain. The contribution of culm reserves to grain yield varied from 1.13 to $19.52 \%$, and 1.09 to $2.11 \%$ in control and in stressed plants, respectively. In conclusion, culm reserve is the important attributes in grain yield in Bangladeshi barley cultivars but the contribution remains almost unaffected due the post-anthesis heat stress.
\end{abstract}

\section{Introduction}

Barley (Hordeum vulgare L.), is an annual grass in the Poaceae (grass family) and is mainly grown for grain purpose. It is also used as forage as well as cover crop to improve soil fertility (Ghanbari et al., 2012). It ranks fifth among crops in grain production in the world after maize, wheat, rice and soybean (Soleymani and Shahrajabian, 2011). In 2015-16, the production of barley in Bangladesh was 7000 metric tons (USDA, 2016). In Bangladesh barley is a minor crop but it has the potential to become one of the important crops in Bangladesh. Barley contains water soluble fibre named beta-glucans and an oil compound named to coronel which are found to be very effective in lowering blood cholesterol level (Hales, 1992).

The grain filling starts with the division of endosperm cells followed by the increase in cell volume through the accumulation of assimilate (Singh and Jenner, 1984). The assimilate for grain filling comes from current assimilation (and subsequent direct translocation to grains) and storage (reserve) pools in vegetative plant parts, especially in the culms (Singh and Jenner, 1984). Water-soluble carbohydrates (WSCs) are considered as the main culm reserves, which may accumulate prior to anthesis and during the initial period of grain filling; and subsequently, they remobilize to developing grains (Ehdaie et al., 2006b; Bingham et al., 2009). Most of the culm WSCs is remobilized to the grains when current assimilation is restricted owing to senescence (Yang et al., 2000; Tahir and Nakata, 2005). So, grain filling in barley depends on two major sources of carbon, namely current photosynthesis in leaves and to some extent in spikes, and mobilization of stored water-soluble carbohydrates (WSC) from the stem into growing grains. When the current photosynthesis is depressed by stresses like drought (Ehdaie et al., 2008), high temperature (Tahir and Nakata, 2005), and foliar diseases (Serrago et al., 2011) grain filling becomes more dependent on mobilized WSCs, and thereby WSCs act as buffers to have a steady rate of grain filling under the post-anthesis stresses by accelerating the remobilization of culm WSCs to grains. The amount of accumulated and mobilized stem reserves are estimated either by monitoring the changes in stem dry weight (Cruz-Aguado et al., 2000; Ehdaie et al., 2006a) or directly by measuring stem WSC content during the grain-filling period (Blum et al., 1994; Ehdaie et al., 2006b). Post-anthesis changes in dry weight (Ehdaie et al., 2006a) and in WSC content (Ehdaie et al., 2006b) of 
the main stem of a diverse set of cultivars indicated that estimation of the amount of stem reserves accumulated and mobilized was dependent on genotype, experimental conditions, and the method of measuring stem reserves.

Generally cereals plant remobilized 50-80\%, 41.2\%, and $13-94 \%$ more culm WSCs to grains under drought (Ehdaie et al., 2008), heat (Tahir and Nakata, 2005), and foliar disease (Serrago et al., 2011) compared with controls, respectively. However, post-anthesis waterlogging, which also restricts the current assimilation, reduces remobilization of culm WSCs (Hossain et al., 2011; Araki et al., 2012). Therefore, the genotypes having the potentiality to accumulate higher amount of WSCs in culms are more tolerant to postanthesis stresses like heat, drought, foliar diseases, etc. (Tahir and Nakata, 2005; Ehdaie et al., 2008; Serrago et al., 2011). Thus, potential accumulation of WSCs in culm and its subsequent mobilization into growing grains are to be considered to select or develop cultivars for stressful environment during grain filling period. However, to best of our knowledge, there is no information about the pattern of grain filling and the contributions of culm WSCs to grain weight in barley cultivars grown in Bangladesh. Therefore, the present piece of study was designed to determine the contribution of culm reserves to grain yield and to screen out the barley genotypes for heat tolerance and having the ability to accumulate more culm reserves with higher efficiency of its remobilization to grain.

\section{Materials and Methods}

Experimental materials: Six cultivars of barley named BARI Barley1, BARI Barley2, BARI Barley3, BARI Barley4, BARI Barley5 and BARI Barley6 were the materials of this study which were collected from Plant Genetic Resource Centre, Bangladesh Agricultural Research Institute (BARI).

Details of experimentation: The experiment was conducted in rabi seasons at the Field Laboratory of Department of Crop Botany, Bangladesh Agricultural University, Mymensingh between November 2015 to March 2016.The experiment was laid out as double factor experiment in Randomized Completely Block Design (RCBD) with 12 treatments and 3 replications. Factor A-six barley cultivars and Factor $\mathbf{B}$-heat treatment (control and heat stress). Heat stress was imposed by late sowing at December 15, 2015. Seeds are sown at November 15, 2015 for control. The experiment consisted of 36 unit plots; each plot was $2 \mathrm{~m}$ $\times 1 \mathrm{~m}$ in size. Plot to plot distance was $0.5 \mathrm{~m}$. There were five rows $0.2 \mathrm{~m}$ apart in a plot. Rows of the plots were oriented in east-west direction. Land was prepared and fertilizers were used in an ideal dose as per the suggestions of the BARI annual Yearbook. Intercultural operations were done as and when necessary as to ensure normal growth of the crops. The plots were irrigated after urea application (at 30 and 60 days after sowing, DAS).

\section{Sampling}

Ten effective tillers were sampled once a week during grain filling period for all cultivars. Grain filling period was defined as the duration from anthesis to physiological maturity. The date of anthesis was determined when the anthers extruded in $50 \%$ of the spikes in the field and the date of physiological maturity was the day when the grain attained its maximum weight. The tillers were separated into culm with sheaths, leaves, and spikes, then heated for $30 \mathrm{~min}$ at $110^{\circ} \mathrm{C}$ and dried for $48 \mathrm{~h}$ at $70^{\circ} \mathrm{C}$, and finally weighed. The grains were separated from the spikes with tweezers and weighed. Average rate of grain filling was estimated as maximum grain weight divided by the duration (Julian days), assuming that grain weight is zero at anthesis (Dias and Lidon, 2009). The culms with leaf sheaths were milled for the measurement of watersoluble carbohydrates (WSCs) using the anthrone method. The weight of structural materials in the culm was determined by subtracting the amount of WSCs in culm from the culm dry weight (Hossain et al., 2009).

\section{Estimation of leaf greenness}

Leaf greenness of the flag leaf and second leaf was measured on different dates during grain filling period in all cultivars with a chlorophyll meter (SPAD-502; Konica Minolta Sensing Inc., Osaka, Japan). SPAD readings were taken at three positions (near base, near apex and middle) of the leaf and were averaged for each leaf. Five leaves were measured, and the readings were averaged for a plot.

\section{Harvesting and data recording}

The plants in a $0.8 \mathrm{~m}^{2}(0.4 \mathrm{~m} \times 2.0 \mathrm{~m})$ area were harvested at maturity for yield and yield components in all cases. The spikes were counted and the plants were dried for $48 \mathrm{~h}$ at $80^{\circ} \mathrm{C}$ and weighed to determine the biomass yield. All spikes were hand-threshed and weighed for grain yield.

\section{Estimation of water soluble carbohydrates (WSCs) in culms}

The WSCs in culms (with leaf sheaths) were extracted and measured using anthrone method (Yemm and Willis, 1954) as described in Hossain et al. (2009, 2010, 2011). The dried culm were chopped and milled to a rough powder. The culm powder were weighed and extracted once with $80 \%$ ethanol at $60^{\circ} \mathrm{C}$ for $30 \mathrm{~min}$ followed by 2 successive 15-min extractions with distilled water at $80^{\circ} \mathrm{C}$. The extracts were combined and evaporated to dryness at $65^{\circ} \mathrm{C}$. The dried carbohydrates were resolved in $5 \mathrm{~mL}$ distilled water. A fraction of the extract solution (about $1 \mathrm{~mL}$ ) was taken in a Micro 
centrifuge tube $(1.5 \mathrm{~mL})$ and charcoal powder was added to it. After mixing the powder and extract solution with a vortex (touch mixer), the solution was centrifuged at $5000(\mathrm{rpm})$ or $5 \mathrm{~min}$ to make a clear solution. The clear solution was diluted 5-10 times with distilled water. Diluted solution $(0.1 \mathrm{~mL})$ was mixed with ice-cold anthrone reagent $(5 \mathrm{~mL})$. The mixture was heated for $10 \mathrm{~min}$ in a boiling-water bath and subsequently cooled with ice water. The absorbance of the reacted solution for standard and samples was measured with a spectrophotometer at $620 \mathrm{~nm}$. The content of WSCs in the sample was calculated as mg WSCs per gram of culm dry mass using regression equation. The amount of WSCs in culm at anthesis, milk ripe and maturity was estimated based on the dry mass of culm harvested at respective stages. The amount of remobilized culm WSCs was estimated from the difference between total culm WSCs at milk ripe/anthesis (maximum WSCs content) and residual culm WSCs at maturity as described (Ehdaie et al., 2006a).

\section{Statistical analysis}

All data were analyzed statistically using statistical package program MSTAT-C and MS office Excel program.

\section{Results}

\section{Yield and yield components}

Yield and yield components were shown in Table 1. The heat stress had significant effect $(\mathrm{P} \leq 0.01)$ on grain yield. The grain yield varied from 52 to $150 \mathrm{~g} \mathrm{~m}^{-2}$ with the mean of $102 \mathrm{~g} \mathrm{~m}^{-2}$ under control while it varied from 37 to $116 \mathrm{gm}^{-2}$ with the mean of $75 \mathrm{~g} \mathrm{~m}^{-2}$ under heat stress. The biomass yield showed significant differences $(\mathrm{P} \leq$ 0.01 ) among the cultivars and also between the stress treatments. It ranged from 662 to 1045 and from 571 to $911 \mathrm{~g} \mathrm{~m}^{-2}$ under control and stress treatment, respectively. Harvest index (HI) significantly $(\mathrm{P} \leq 0.01)$ varied with the cultivars and also with the heat stress. It ranged from 5.65 to $15.87 \%$ and from 6.40 to $13.46 \%$ under control and stress treatment, respectively. The number of spikes per square meter exhibited significant differences $(\mathrm{P} \leq 0.01)$ among the cultivars and also between the stress treatments with the range of 168-198 and 127-183 under control and the heat stress, respectively. The number of grains per spike also exhibited significant differences $(\mathrm{P} \leq 0.01)$ among the cultivars also between the stress with the range of 8.9221.36 and 7.94-15.53 under control and the stress, respectively. The thousand grain weight varied significantly $(\mathrm{P} \leq 0.01)$ with cultivars and also with the stress treatment. It varied from 26.80 to $39.73 \mathrm{~g}$ with the mean of $34.91 \mathrm{~g}$ and from 23.33 to $36.13 \mathrm{~g}$ with the mean of $29.69 \mathrm{~g}$ under control and stressed condition, respectively.

Table 1. Grain yield, biomass yield, harvest index and yield attributes in six barley cultivars as affected by the heat stress during grain filling period

\begin{tabular}{llcccccc}
\hline Cultivars & Heat stress & $\begin{array}{c}\text { Grain } \\
\text { yield } \\
\left(\mathrm{g} \mathrm{m}^{-2}\right)\end{array}$ & $\begin{array}{c}\text { Biomass yield } \\
\left(\mathrm{g} \mathrm{m}^{-2}\right)\end{array}$ & $\begin{array}{c}\text { Harvest } \\
\text { index } \\
(\%)\end{array}$ & $\begin{array}{c}\text { Spikes } \\
\mathrm{m}^{-2}\end{array}$ & $\begin{array}{c}\text { Grains } \\
\text { spike }\end{array}$ & $\begin{array}{c}\text { 1000-seed } \\
\text { weight }(\mathrm{g})\end{array}$ \\
\hline BARI Barley1 & Control & 131 & 1045 & 13.40 & 197.90 & 17.61 & 37.87 \\
& Stressed & 101 & 896 & 11.33 & 147.90 & 13.63 & 36.13 \\
BARI Barley22 & Control & 138 & 1007 & 13.33 & 184.60 & 18.99 & 39.73 \\
& Stressed & 115 & 911 & 12.65 & 183.30 & 12.97 & 29.07 \\
BARI Barley3 & Control & 52 & 755 & 5.65 & 186.70 & 8.92 & 30.13 \\
& Stressed & 38 & 594 & 6.40 & 127.10 & 7.94 & 26.80 \\
BARI Barley4 & Control & 75 & 662 & 11.46 & 167.90 & 12.64 & 35.33 \\
& Stressed & 40 & 571 & 6.96 & 158.30 & 9.42 & 23.33 \\
BARI Barley55 & Control & 150 & 961 & 15.87 & 179.20 & 21.36 & 39.07 \\
& Stressed & 116 & 864 & 13.46 & 164.60 & 15.53 & 35.47 \\
BARI Barley6 & Control & 66 & 683 & 9.78 & 175.00 & 13.98 & 30.67 \\
& Stressed & 43 & 578 & 7.44 & 139.60 & 11.03 & 27.37 \\
Significance & Cultivar $(\mathrm{C})$ & $* *$ & $* *$ & $* *$ & $* *$ & $* *$ & $* *$ \\
& Stress $(\mathrm{S})$ & $* *$ & $* *$ & $* *$ & $* *$ & $* *$ & $* *$ \\
& C $\times \mathrm{S}$ & $* *$ & $\mathrm{NS}$ & $* *$ & $* *$ & $* *$ & $* *$ \\
\hline
\end{tabular}

** Significant at $1 \%$ level of probability, NS =Not significant 
Table 2. Phenological characters, grain filling rate and maximum grain weight in six barley cultivars as affected by the heat stress during grain filling

\begin{tabular}{llccccc}
\hline Cultivars & Heat stress & $\begin{array}{c}\text { Grain } \\
\text { filling } \\
\text { duration (d) }\end{array}$ & $\begin{array}{c}\text { Days to } \\
\text { anthesis (d) }\end{array}$ & $\begin{array}{c}\text { Days to } \\
\text { physiological } \\
\text { maturity (d) }\end{array}$ & $\begin{array}{c}\text { Grain filling } \\
\text { rate (mg } \\
\left.\text { grain }^{-1} \mathrm{~d}^{-1}\right)\end{array}$ & $\begin{array}{c}\text { Maximum } \\
\text { grain weight } \\
\text { (mg grain }^{-1} \text { ) }\end{array}$ \\
\hline BARI Barley1 & Control & 35 & 74 & 109 & 0.7600 & 26.44 \\
& Stressed & 19 & 67 & 88 & 1.550 & 29.51 \\
BARI Barley2 & Control & 35 & 74 & 109 & 0.9400 & 32.88 \\
& Stressed & 19 & 67 & 88 & 1.400 & 26.68 \\
BARI Barley3 & Control & 35 & 74 & 109 & 0.7200 & 25.06 \\
& Stressed & 19 & 67 & 88 & 1.310 & 24.94 \\
BARI Barley4 & Control & 35 & 74 & 101 & 0.6900 & 29.17 \\
& Stressed & 19 & 67 & 88 & 1.280 & 24.41 \\
BARI Barley5 & Control & 42 & 67 & 101 & 0.7800 & 32.90 \\
& Stressed & 21 & 65 & 86 & 1.370 & 28.76 \\
BARI Barley6 & Control & 42 & 67 & 88 & 0.4500 & 18.71 \\
& Stressed & 21 & 65 & 86 & 1.210 & 25.46 \\
Significance & Cultivar (C) & $* *$ & $* *$ & $* *$ & $* *$ & $* *$ \\
& Stress (S) & $* *$ & $* *$ & $* *$ & $* *$ & $*$ \\
& CxS & $* *$ & $*$ & $* *$ & $* *$ & $* *$ \\
\hline
\end{tabular}

** Significant at $1 \%$ level of probability, * Significant at $5 \%$ level of probability

\section{Phenological characters and grain filling rate}

The grain-filling period (GFP) significantly varied $(\mathrm{P} \geq$ $0.01)$ with the cultivars and the stress treatments (Table 2). It ranged from 35.0 to 42.0 with the mean of 37.33 under control. Heat stress drastically reduced the grain filling duration. GFD ranged from 19 to 21.0 with the mean of 19.67 under the heat stress. Barley cultivar, BARI Barley5, BARI Barley6 possessed longest grain filling period (42 d) and BARI Barley1, BARI Barley2, BARI Barley3 and BARI Barley4 possessed shortest period (35 d) under normal sowing while BARI Barley5, BARI Barley6 possessed longest grain filling period (21 d) and BARI Barley1, BARI Barley2, BARI Barley3 and BARI Barley4 possessed shortest period (19 d) under heat stress. The days to anthesis showed significant $(\mathrm{P} \geq 0.01)$ differences between the cultivars and also between the heat treatments. It ranged from 67 to 74 and from 65 to 67 days under control and stress condition, respectively. The days to physiological maturity $(\mathrm{PM})$ also varied significantly $(\mathrm{P} \geq 0.01)$ with the cultivars and with the stress treatment. It ranged from 88 to 109 and from 86 to 88 days under control and stress condition. BARI Barley1 and BARI Barley2 required longest time $(109$ d) and BARI Barley6 required shortest time (86 d) to attain PM under control condition.

The average grain-filling rate exhibited significant ( $P$ $\geq 0.01$ ) variation among the cultivars. It also varied with the heat treatment. The range and mean of average grain filling rate are $0.45-0.78$ and $0.64 \mathrm{mg}_{\text {grain }}{ }^{-1}$ day $^{-1}$, respectively under normal sowing. The heat stress increased the grain filling rate with the range and mean of $1.21-1.55$ and $1.35 \mathrm{mg}$ grain $^{-1}$ day $^{-1}$, respectively. Generally, the high yielding cultivars (e.g. BARI Barley5, BARI Barley2, BARI Barley1) showed comparatively higher grain filling rate compared to the low yielding cultivars (e.g. BARI Barley3).

\section{Grain growth}

The grain growth measured with the changes in grain dry weight during the grain-filling period is shown in Fig. 1. The grain dry weight increased slowly during initial days of grain filling followed by a rapid increase until physiological maturity (PM) in almost all cultivars. However, the increasing patterns varied with the cultivars and also with the heat treatments. The stressed wheat plants exhibited sharper grain growth from the early phase of grain filling with earlier cessation of grain growth resulting in lighter grain weight at maturity compared to control. The cultivars with higher grain yield (e.g. BARI Barley5, BARI Barley2, BARI Barley1 etc.) showed comparatively sharper trends compared to the cultivars with lower grain yield (e.g. BARI Barley4, BARI Barley6 and BARI Barley3) under control condition while BARI Barley5, BARI Barley2, BARI Barley1 possessed sharper grain growth under stress condition compared to other cultivars. In addition there was variation in the cessation of grain growth among the cultivars.

\section{Changes in total dry mass}

The changes in total dry mass (TDM) of six barley cultivars during the grain filling period are shown in 
Fig. 2. The cultivars showed variations in TDM at anthesis and in post anthesis changes of TDM. Here cultivars (e.g. BARI Barley1, BARI Barley2, BARI Barley6) exhibited higher TDM at an thesis compared to cultivars (e.g. BARI Barley5, BARI Barley4, BARI Barley3) under normal sowing while cultivars (e.g.

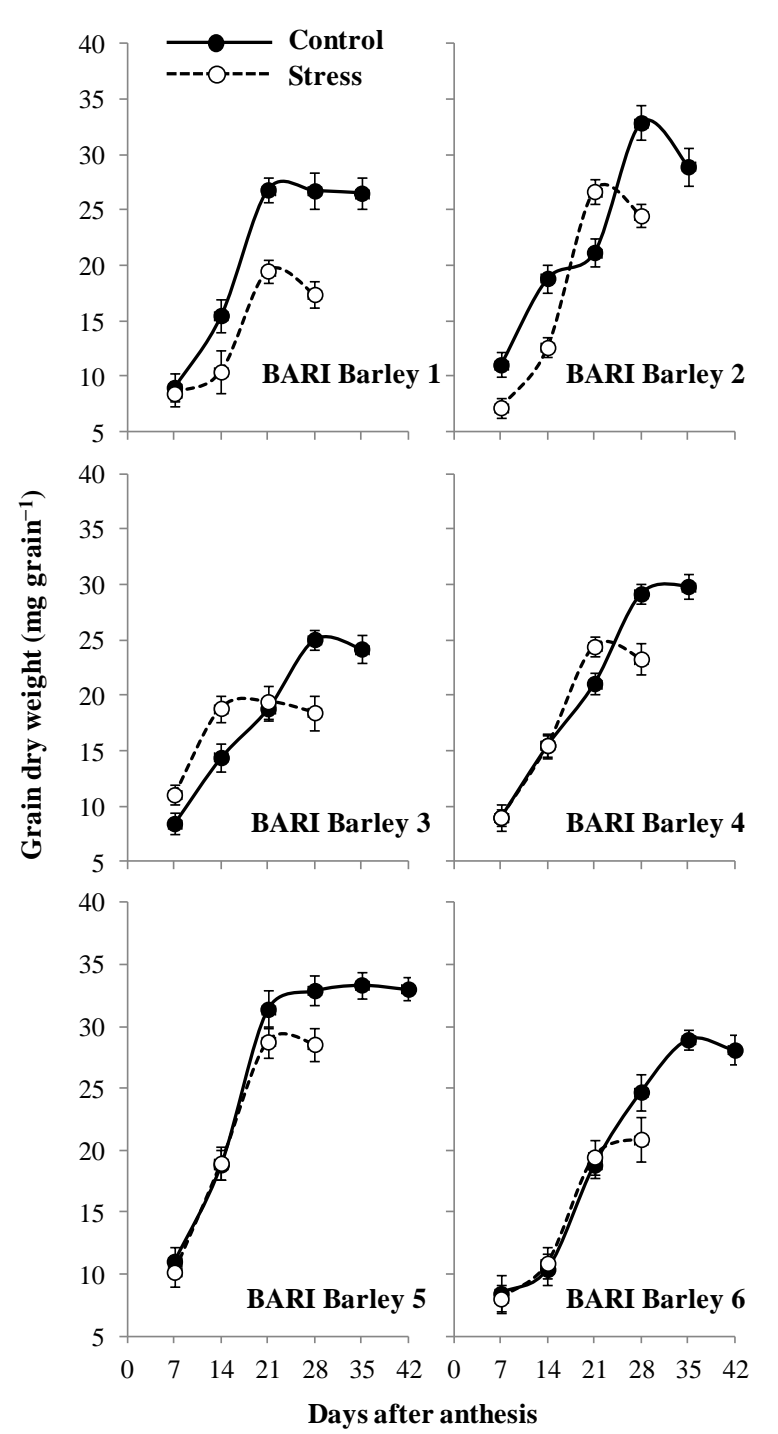

Fig. 1. Grain growth patterns in six barley cultivars as affected by heat stress during grain filling period. The vertical bar represents SEM $(n=3)$

BARI Barley6, BARI Barley5, BARI Barley2) exhibited higher TDM at anthesis compared to cultivars (e.g. BARI Barley4, BARI Barley1 and BARI Barley3) under heat stress condition.

\section{Changes in leaf greenness}

The leaf greenness of flag leaves evaluated by SPAD readings is shown in Fig. 3. The SPAD reading was about 50 in almost all cultivars at anthesis. However, the cultivars exhibited variations in changing pattern of SPAD reading during grain filling period. In general, high yielding cultivars (e.g. BARI Barley5, BARI
Barley6 and BARI Barley2) retained leaf greenness longer time (up to 14 to 21 DAA) than in low yielding cultivars (e.g. BARI Barley4, BARI Barley1 and BARI Barley3). Usually, low yielding cultivars exhibited the declining trends in SPAD readings from anthesis towards maturity.

\section{Changes in WSCs in culm reserves}

Fig. 4 showed that there were large variations in the content of WSCs in culm at different times during grain filling. The increase in WSCs content in culm shows post anthesis accumulation of culm reserves and the decrease in WSCs contents shows the remobilization of the reserves to the grains. The WSCs content at anthesis varied from 7.75 to 18.50 and from 5.89 to $9.25 \mathrm{mg}$ culm $^{-1}$ dry mass under control and stress environment, respectively. The WSCs content at milk ripe stage varied from 4.01 to 10.11 and from 3.55 to $10.76 \mathrm{mg}$ culm $^{-1}$ dry mass under control and stress environment, respectively. The highest value of WSCs content was recorded in BARI Barley1 and the lowest value in BARI Barley3. In general, high yielding cultivars possessed higher WSCs content at milk ripe compared to low yielding cultivars. The cultivars also exhibited variations in the residual WSCs content in culm at maturity. The

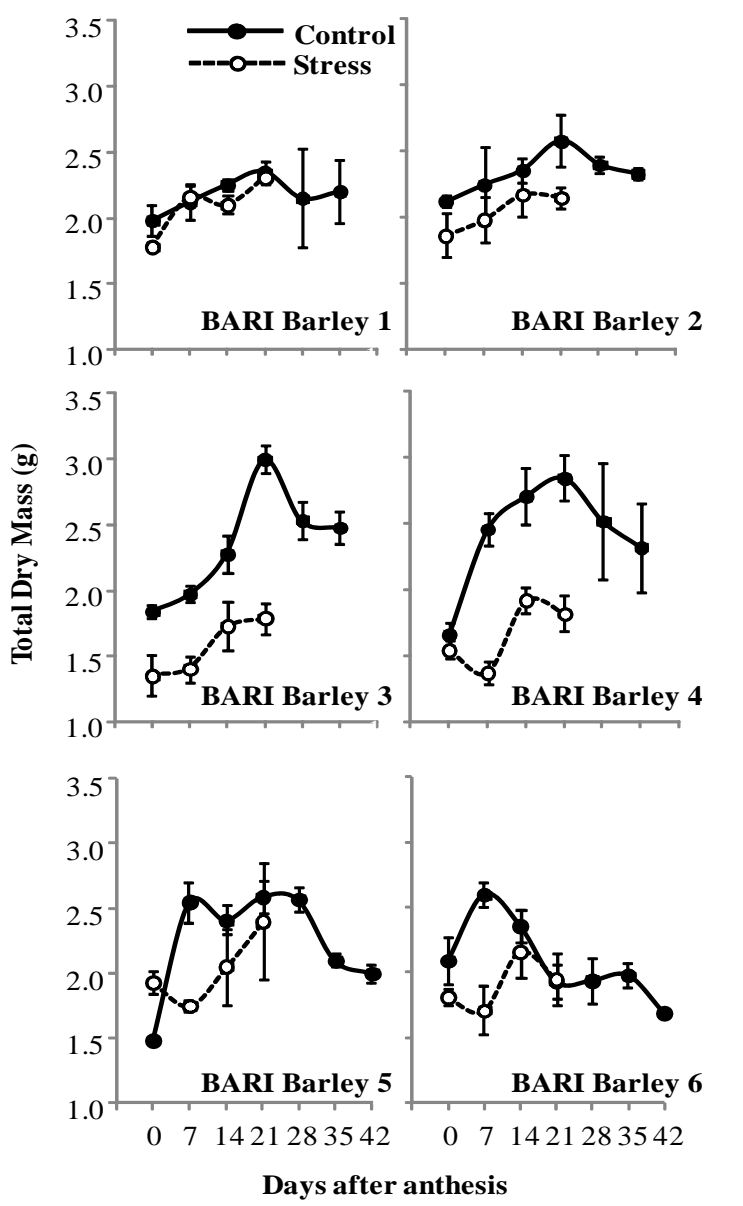

Fig. 2.Total dry mass (TDM) in six barley cultivars as affected by heat stress during grain filling period. Vertical bar represents standard error of means $(n=3)$ 
WSCs content at maturity stage varied from 2.84 to 6.08 and from 2.68 to $6.25 \mathrm{mg} \mathrm{culm}^{-1}$ dry mass under control and stress environment, respectively. The highest value was recorded in BARI Barley5 and minimum in BARI Barley3.

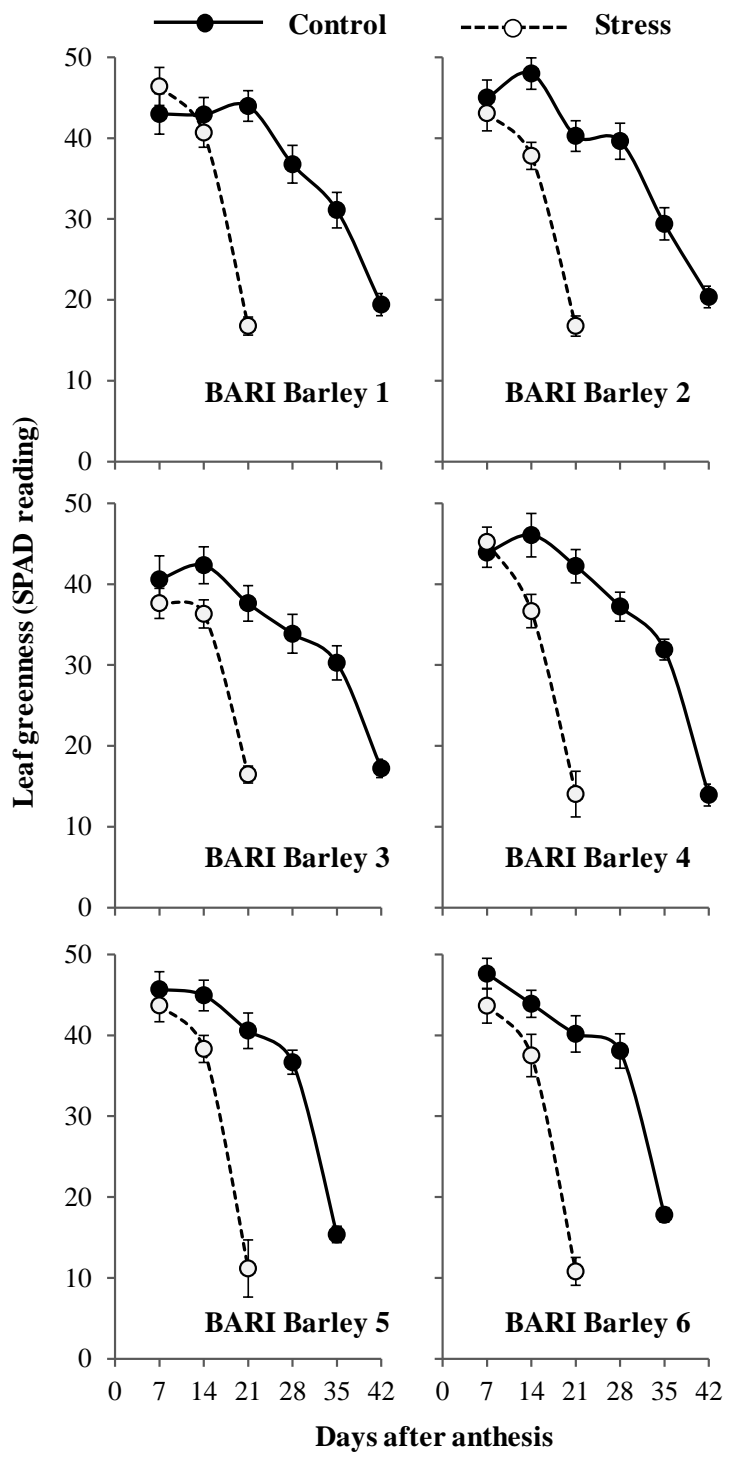

Fig. 3. Leaf greenness in flag leaves of six barley cultivars as affected by heat stress during grain filling period. The vertical bar represents SEM $(n=3)$

\section{Discussion}

Significant variations in grain yield and yield attributes are exhibited by six barley cultivars which are used in this experiment. The heat stress imposed by late sowing significantly reduced grain yield (Table 1). Grain yield in barley is determined by 3 yield components i.e., number of spikes $\mathrm{m}^{-2}$, number of grains spike $^{-1}$ and 1000 -grain weight. Though all the components showed significant variations in $\mathrm{F}$ test, the $\mathrm{F}$ value indicates that grain weight is the most important components for the variations and also reduction in grain yield (Table 1). Grain weight is determined during the grain filling period, the period between anthesis and physiological maturity. Grain filling is the accumulation of assimilates in grains during the grain filling (Austin et al., 1980). The assimilates for grain filling come from current photosynthesis and stored reserves in culm (Austin et al., 1980; Hossain et al., 2011). In this study, under control treatment, cultivars producing higher grain yield (BARI Barley5, BARI Barley2 and BARI Barley1)) showed sharper grain growth from anthesis towards physiological maturity (Fig.1) with increased grain filling rate (Table 2) compared to low yielders (BARI Barley4, BARI Barley6 and BARI Barley3). Though grain filling duration is one of the important factors for producing heavier grains it has no positive correlation with the grain size in this experiment and under heat stress treatment, Barley cultivars producing higher grain yield (BARI Barley5, BARI Barley2, BARI Barley1) showed sharper grain growth from anthesis towards physiological maturity (Fig.1) with increased grain filling rate (Table 2) compared to low yielders (BARI Barley4, BARI Barley6, BARI Barley3) which resulted in heavier grains (Fig.1) in the high yielding cultivars.

The days to anthesis ranged from 67 to 74 and from 65 to 67 days under control and stress condition, respectively (Table 2). It showed differences between the cultivars and also between the heat treatments. The difference in grain filling among the cultivars could be accounted for by the difference in post-anthesis carbon

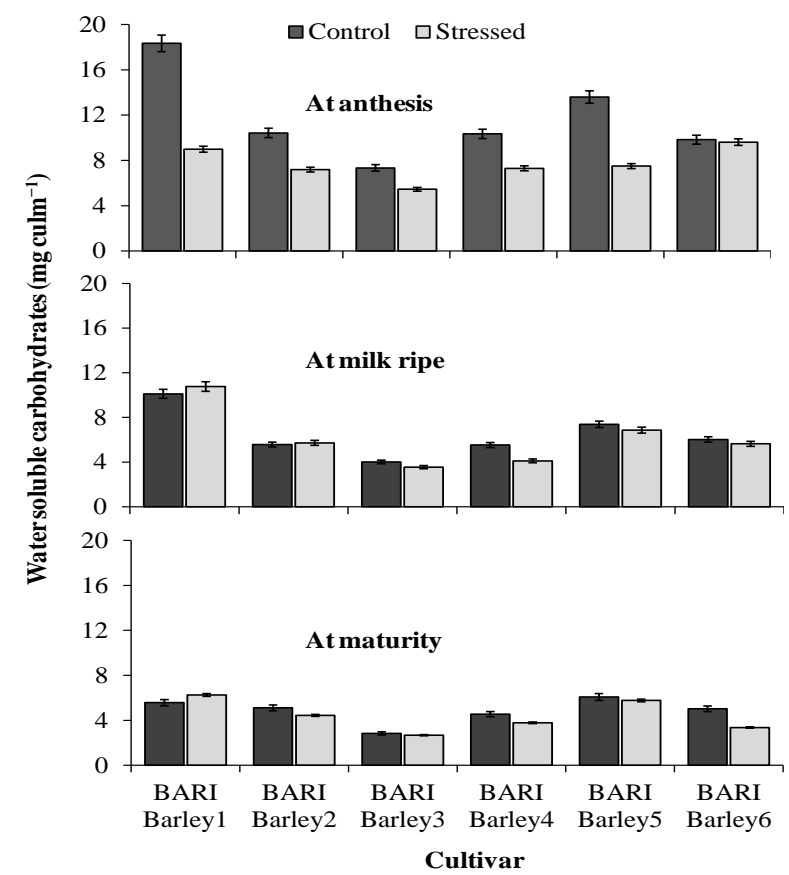

Fig. 4. Water soluble carbohydrates (WSCs) in culms at anthesis, milk ripe and maturity in six barley cultivars as affected by heat stress during grain filling period. The vertical bar represents $\operatorname{SEM}(\mathrm{n}=3)$ 
assimilation and culm reserves remobilized to grains (Takahashi et al., 1993; Hossain et al., 2009). Carbon assimilation can be monitored by the changes in total dry mass (Hossain et al., 2009). The high yielding cultivars usually exhibited greater accumulation of TDM (Fig. 2) compared to low yielding ones.

The culm reserves play a vital role in buffering grain yield when current assimilation is restricted as senescence due to heat stress (Tahir and Nakata, 2005). The culm elongates and stores water-soluble carbohydrates (WSCs) during initial and early period of grain filling (from anthesis to milk ripe, at around 14 DAA) and they are remobilized to grains during the late and final period (from milk ripe to maturity) (Takahashi et al., 1993). There were wide variations in the accumulation and remobilization of culm WSCs among the cultivars studied. Usually high yielders had the ability to accumulate more WSCs in culms with the varied degree of remobilization and contribution to grain yield. For example, the culm of BARI Barley1 contained $10.11 \mathrm{mg}$ WSCs at milk ripe stage while it contained $5.57 \mathrm{mg}$ WSCs at maturity contributing 4.54 mg WSCs for final grain weight. In contrary, BARI Barley 3 contained 5.57 and $5.11 \mathrm{mg}$ WSCs at milk ripe and maturity, respectively indicating contributes only $0.46 \mathrm{mg}$ WSCs for final grain weight. However, the accumulation and remobilization were largely influenced by the heat stress (Fig. 4). The cultivars having ability to accumulate more Culm reserves like BARI Barley5, BARI Barley1 and BARI Barley6 exhibited better in respect of grain yield under the stress.

\section{Conclusion}

The cultivars exhibited variations in remobilization of culm WSCs to grains. The contribution, in general, was higher in high yielders compared to low yielders. It may be concluded that, the grain weight is most important factor causing large variations in grain yield among barley cultivars grown in Bangladesh. Both the current assimilation and remobilized culm reserves are attributable to the grain weight. High yielding cultivars especially BARI Barley5, BARIBarley2 and BARI Barley1 have the higher potentiality to buffer grain yield under limited current assimilation as they can store higher amount of WSCs in culm.

\section{Acknowledgement}

This research was supported by a Research Grant (2016/46/AU-GC) from University Grants Commission of Bangladesh

\section{References}

Araki, H., Hamada, A., Hossain, M.A. and Takahashi, T., 2012. Water logging at jointing and/or after anthesis in wheat induces early leaf senescence and impairs grain filling. Field Crops Res. 137: 27-36.

Austin, R.B., Morgan, R.B., Ford, M.A. and Blackwell, R.D., 1980. Contributions to grain yield from pre-anthesis assimilation in tall and dwarf barley genotypes in two contrasting seasons. Ann. Bot. 45: 309-316.

Bingham, I.J., Walters, D.R., Foulkes, M.J. and Paveley, N.D., 2009. Crop traits and the tolerance of wheat and barley to foliar disease. Ann. Appl. Biol. 154: 159-173.

Blum, A., Sinmena, B., Mayer, J., Golan, G. and Shipiler, L., 1994. Stem reserve mobilization supports wheat grain filling under heat stress. Aust. J. Plant Physiol. 21: 771-781.

Cruz-Aguado, J.A., Rode's, R., Pe'rez, I.P. and Dorado, M., 2000.Morphological characteristics and yield components associated with accumulation and loss of dry matter in internodes of wheat. Field Crops Res. 66: 129-139.

Dias, A.S. and Lidon, F.C., 2009. Evaluation of grain filling rate and duration in bread and durum wheat under heat stress after anthesis. J. Agron. Crop Sci. 195: 137-147.

Ehdaie, B., Alloush, G.A. and Waines, J.G., 2008. Genotypic variation in linear rate of grain growth and contribution of stem reserves to grain yield in wheat. Field Crops Res. 106: $34-43$.

Ehdaie, B., Alloush, G.A., Madore, M.A. and Waines, J.G., 2006a. Genotypic variation for stem reserves and mobilization in wheat. I. Post anthesis changes in internode dry matter. Crop Sci. 46: 735-746.

Ehdaie, B., Alloush, G.A., Madore, M.A. and Waines, J.G., 2006 b. Genotypic variation for stem reserves and mobilization in wheat. II Post anthesis changes in internode water-soluble carbohydrates. Crop Sci. 46: 2093-2103.

Ghanbari, A., Babaeian, M., Esmaeilian, Y., Tavassoliand, A. and Asgharzade, A., 2012. The effectof cattle manure and chemical fertilizer on yield and yield component of barley (Hordeum vulgare). Afr. J. Agric. Res. 7: 504-508.

Hales, D., 1992. Eat smart, feed good, look great. Reader's Digest. April, Issue. P. 63.

Hossain, A., Sarker, M.A.Z., Saifuzzaman, M., Teixeira da Silva, J.A., Lozovskaya, M.V. and Akhter, M.M., 2010. Evaluation of growth, yield, relative performance and heat susceptibility of eight wheat ( Triticum aestivum L.) genotype grown under heat stress. Intl. J. Plant Prodz. 7: 615-636.

Hossain, A., Sarker, M.A.Z., Hakim, M.A., Lozovskaya, M.V. and Zvolinsky, V.P., 2011. Effect of temperature on yield and some agronomic characters of spring wheat (Triticum aestivum L.) genotypes. Int. J. Agril. Res. Innov. Tech. 1: $44-54$.

Hossain, A., Sarker, M.A.Z., Saifuzzaman, M., Akhter, M.M. and Mandal, M.S.N., 2009. Effect of sowing dates on yield of wheat varieties and lines developed since 1998. Bangladesh J. Prog. Sci. Tech. 7: 5-8.

Serrago, R.A., Carretero, R., Bancal, M.O. and Miralles, D.J., 2011. Grain weight response to foliar diseases control in wheat (Triticum aestivum L.) and barley (Hordium vulgare). Field Crops Res. 120: 352-359.

Singh, B.K. and Jenner, C.F., 1984. Factors controlling endosperm cell number and grain dry weight in wheat and barley with effects of shading on intact plants and of variation in nutritional supply to detached, cultured ears. Aust. J. Plant Physiol. 11: 151-163.

Soleymani, A. and Shahrajabian, M.H., 2011. Influence of planting date and plant density on grain and biological yields of barley cultivars. Research on Crops. 12: 698-700.

Tahir, I.S.A. and Nakata, N., 2005. Remobilization of nitrogen and carbohydrate from stems of bread wheat and barley in response to heat stress during grain filling. J. Agron. Crop Sci. 191: 106-115.

Takahashi, T., Tsuchihashi, N. and Nakaseko, K., 1993. Grain filling mechanisms in spring wheat. I. Grain filling phases according to the development of plant organs. Jpn. J. Crop Sci. 62: 560-564. 
USDA, 2017. Crop Production 2016 Summary, United States Department of Agriculture National Agricultural Statistics Service.

Yang, J., Zhang, J., Huang, Z., Zhu, Q. and Wang, L., 2000. Remobilization of carbon reserves is improved by controlled soil-drying during grain filling of wheat. Crop Sci. 40: $1645-1655$.

Yemm, E.W. and Willis, A.J., 1954.The estimation of carbohydrates in plant extracts by anthrone. Biochem. J. 57: 508-514. 